\title{
双方向型空気圧コンプレッサの開発と応用*
}

\author{
吉 満 俊 拓 ${ }^{* *}$, 藤 田 貴 吉***, 小山 紀****
}

\section{Development and Application of Alternate Direction Air Compressor}

\author{
Toshihiro YOSHIMITSU, Takayoshi FUJITA, Osamu OYAMA
}

This paper proposes a new type of compressor that can discharge air in alternate directions. This compressor can operate the direction/speed of a cylinder by changing the clockwise/counterclockwise rotational direction and the rotational speed of the compressor, and also does not need additional solenoid control valves. The key issue here is to develop an alternate direction air compressor having effective performance. In this report, we verify the fundamental characteristics and advantages of this compressor. We also investigate the possibility a cylinder system using this new type of compressor.

Key words : Alternate Direction Air Compressor, Air Motor

\section{1. 緒言}

コンプレッサの形態として，運転制御により吸引と加圧 を相互方向に切り替えできる双方向型もあり，油圧制御回 路ではこのような双方向型がしばしば用いられる文， 。 かしながら空気圧回路では使われることはなかった。

空気圧回路においても，個々のアクチュエータに専用の コンプレッサを配置するシステムを構成すれば，油圧の場 合と全く異なった観点からその利点を指摘できる ${ }^{3), 4}$. 油 と異なり空気の圧縮性は格段に大きく，この機能を用いた 様々な利用が考えられる，すなわち，単に，騒音や污れな どで嫌われる排気を皆無にできるのみではない. アクチュ エータ内に空気を封じ込めたまま同じ空気を加圧・吸引し て用いれば，アクチュエータの動作剛性を高くすることが できる。この場合，付属的な制御機器，すなわち方向制御 弁や速度制御弁を全く必要とせず，コンプレッサの運転転 操作により，アクチュエータの動作方向や速度の制御が直 接できる。また，アクチュエータの排気をコンプレッサで 回収すれば，従来破裹していた圧縮空気の膨張エネルギを 再利用できる。

本研究ではこのような用途に耐える双方向型コンプレッ サが製品にはないことから，まず，双方向型コンプレッサ

\footnotetext{
*平成 23 年 6 月 30 日 原稿受付

**神奈川工科大学工学部ロボット・メカトロニクス学科

(所在地 戸243-0292 神奈川県厚木市下荻野1030)

***ヤマハ発動機

(所在地 テ435-0054 静岡県浜松市中区早出町882)

****明治大学理工学部機械情報工学科

(所在地 ₹214-8571 神奈川県川崎市多摩区東三田 1-1-1)
}

を開発する，つぎに，このコンプレッサを用いた空気圧シ リンダ制御システムを構成し, 予想される利点を確認して $ゆ<$.

\section{2. 双方向型コンプレッサの構成}

\section{1 構成デバイス}

加圧・吸引側が相互に逆転できる小型の双方向型コンプ レッサを開発するにあたり，注目したのは空気圧モータで ある。これは軸の回転方向を逆転すると, 排出と吸引が可 逆になるベーン型であり，さらに内部が軸の回転方向に対 し完全に対称な構造をもつ. 本来の機能はアクチュエー夕 であるが, 電動モータとカップリングを用いて接続し可逆 運転させて双方向型コンプレッサとして動作させた.

電動モー夕への電力供給用インバータと指令信号を与え るマイコンを加え, 全体の構成を双方向型コンプレッサと 呼ぶ。なお，電動モー夕はAC型であり，インバータから 印加される交流電力の周波数によりコンプレッサの回転数, すなわち出力が操作される. Fig. 1に双方向型コンプレッ

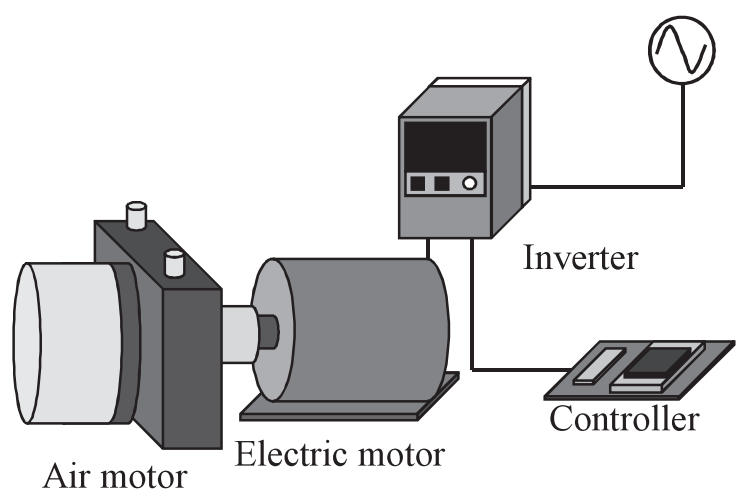

Fig. 1 Alternate Direction Air Compressor 
サの概略を示す。

\section{2 試作した双方向型コンプレッサの特性}

双方向型コンプレッサは, 動作の方向が異なっても同じ 能力を持つことが望ましい. コンプレッサの回転方向を正 ·逆両回転させ，それぞれの方向への出力特性を測定した. インバータの発生周波数と吐出圧力・流量の関係をFig. 2 と Fig. 3に示す.コンプレッサの吐出側負荷は一定として内 径 $2 \mathrm{~mm}$ の固定絞りを用いている. 吸引側は大気圧である.

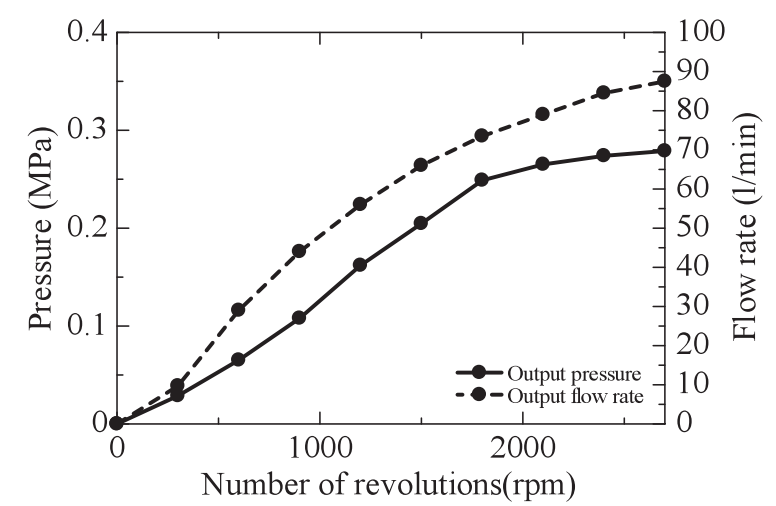

Fig. 2 Discharged pressure and flow vs frequency (CW)

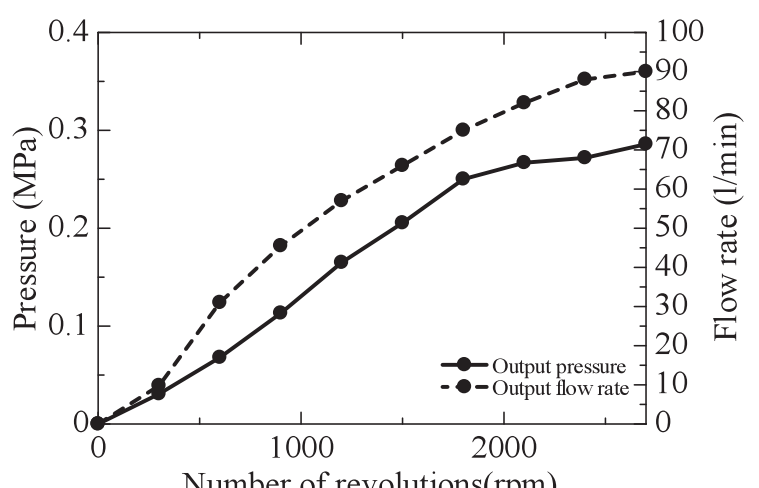

Fig. 3 Discharged pressure and flow vs frequency (CCW)

これらの図から出力方向を切替えても同程度の能力を 持っていることがわかる.この負荷に扔ける最大吐出圧力 は約0.3Mpa (ゲージ圧), このときの出力は $350 \mathrm{w}$ となり, 空気圧シリンダを駆動させるには十分な能力があった.

双方向型コンプレッサは, 回転方向によって圧縮空気が 吐出される方向が切替わる. 空気が吐出されないほうは吸 引口となる. 双方向型コンプレッサの吸引特性を調べた結 果をFig. 4 とFig. 5に示す. 吸引側は先の吐出側に用いた固 定絞りを取り付け，吐出側は大気に放出させた.

吐出特性と同様に回転方向を切替えても吸引能力に差が ないことが認められる. インバー夕周波数を増してゆくと 約 $-0.8 \mathrm{Mpa}$ （ゲージ圧）までの負圧になる。 このときの絞 りからの流入量は約 $80 \ell / \mathrm{min}$ である. 試作した双方向型コ ンプレッサは吸引ポンプとしても使えることがわかる. 負 圧を利用したシステムへの応用も考えられる。

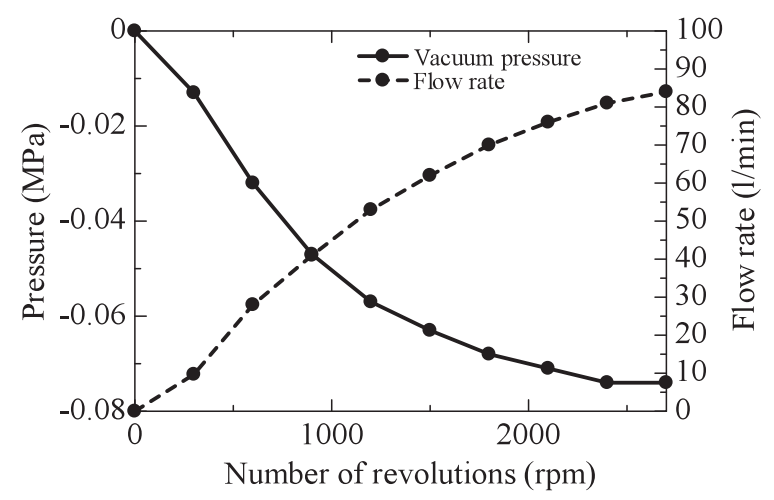

Fig. 4 Suction pressure and flow vs frequency (CW)

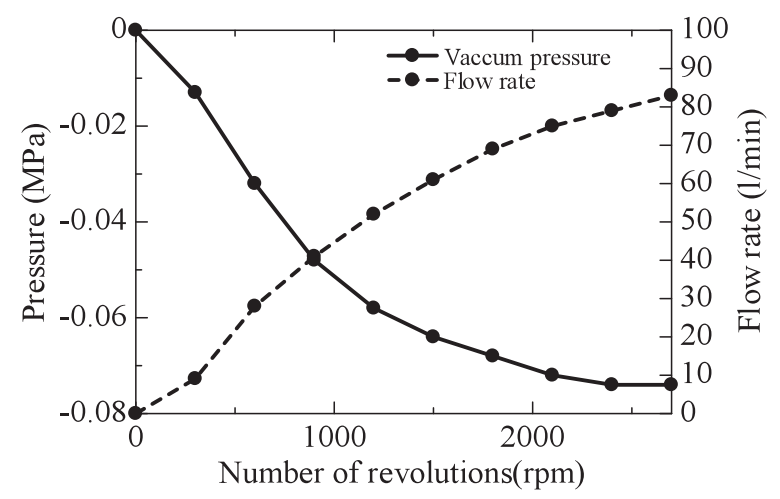

Fig. 5 Suction pressure and flow vs frequency (CCW)

\section{3. 双方向型コンプレッサを用いたシリン名駆動}

\section{1 構成回路}

双方向型コンプレッサを空気圧シリンダ駆動に用いる場 合, Fig. 6のような構成が考えられる. 個々のシリンダに 専用の小型コンプレッサを㧍く，長い配管や減圧機構は不 要でコンパクトにできる. 専用コンプレッサでは, 排気空 気の持つ膨張エネルギの回生が可能である。すなわち、コ ンプレッサの吸引側は排気側シリンダの空気が入力される. シリンダの移動方向の逆転時には高圧となっている吸引空 気がコンプレッサの回転子を押すことでエネルギ回生がお こなわれる。

シリンダの方向制御，速度制御などは全てコンプレッサ

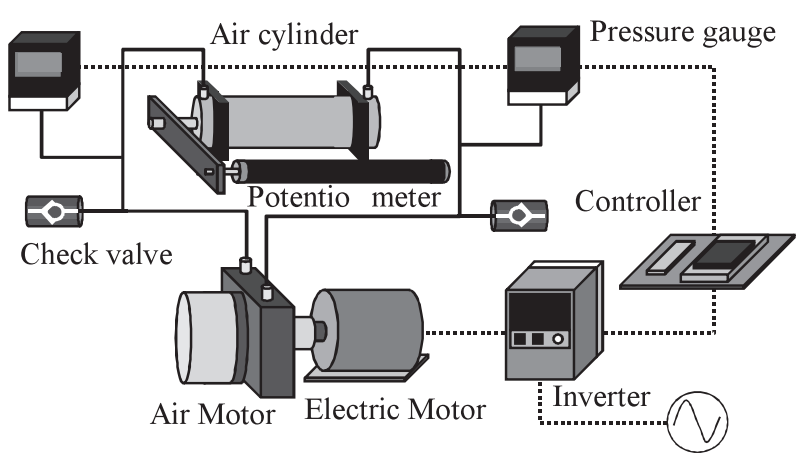

Fig. 6 Air drive circuit by alternate direction air compressor 
の回転制御によりおこなわれるため方向制御弁や速度制御 弁は不要である. しかし, この構造は本質的にシリンダ内 空気のみを使うことになるので, 動作開始直後には必要な 空気を大気からシリンダ内に吸引する必要があり, シリン ダ両側にチェック弁を設けた.

双方向型コンプレッサを使用する場合の優位性を検証す る目的で, 同じコンプレッサを一般的な単方向型コンプ レッサとして使用するFig. 7に示すようなシリンダ制御回 路を構成した。コンプレッサは常に正回転し吸引は大気か ら行い圧縮空気を供給する。これを大気吸引回路と呼ぶこ ととする。シリンダの移動方向の変更は方向制御弁を用い る. 具体的な手順として,

ロッド収縮時は，電磁弁(1)(3)を開・(2)(4)を閉とする. ロッド伸長時は，電磁弁(1)(3)を閉・(2)(4)を開とする.

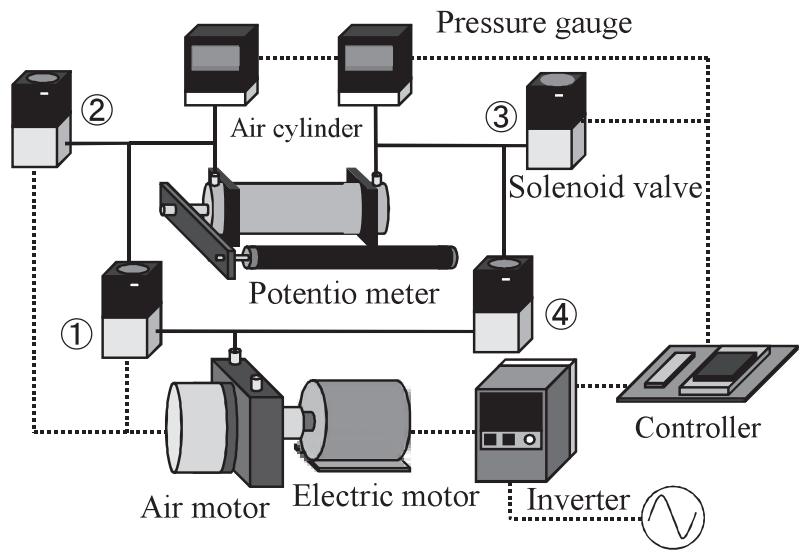

Fig. 7 Air drive circuit by air suction system

双方向型コンプレッサを空気圧シリンダ駆動に用いる場 合の利点を整理すると，

i ）方向制御弁や速度制御弁を必要とせず，コンプレッサ の操作のみで動作方向, 速度や位置などの制御ができ る

ii ）空気の排出がないので，排気による污染や排気音が嫌 われる環境で使える

iii）従来破棄されていた圧縮空気のエネルギ回生が行われ るので省エネルギとなる

である。これらを順に確認してゆく

今回，二種類のシリンダ駆動回路を使用しマイコンの制 御によりシリンダロッドを 5 往復させる. そして, 空気の 積算供給流量, 消費電力量の理論值と実験值を測定し比較 していくことで, 双方向型コンプレッサを用いたシステム の優位性を検証していく.

\section{2 オープンループ制御によるシリンダの速度制御}

速度制御弁を使った従来の速度制御では，予期しない二 次的なシリンダ内圧力変化が発生したり，シリンダ摺動面 の影響を受けやすいなどの現象が知られている。このため, 特に低速度制御が難しい。一方，提案する駆動回路は空気
がシリンダ内に絶えず封止されており, 移動に必要な空気 量はコンプレッサにより管理されているため，動きに対す る剛性が高く，速度制御において優位であると考えられる。

まずはコンプレッサの回転操作でシリンダを速度制御で きることを確認する，供試シリンダは内径 $20 \mathrm{~mm}$ 行程 $150 \mathrm{~mm}$ で横置きとした．移動方向と指定速度はTable 1のように, 表の上から順に10段階の速度に切替えて実施する. 表の左 は速度切替えを指示する位置，中はその時点における前の 指示位置からの変位である．右は指定速度でマイコンから のビット值で示されている. ビット值はインバー夕周波数 に比例し, ビット值が大きい程インバータの周波数は高く なる. すなわち, 最初は $0 \mathrm{~mm}$ の位置から $75 \mathrm{~mm}$ まて正方向に 50ビットで指示された速度で移動し，75m に達すると56.25 $\mathrm{mm}$ の位置まで逆方向に10ビットの速度で移動し, 最終的に 10段階まで種々の速度で交互方向に移動する。なお，この 速度制御はインバー夕周波数のみを操作しているため本質 的にオープンループ制御である.

Table 1のプログラムを実行したときのシリンダ変位の様 子をFig. 8に示す. 指定速度ビット值, ポンプ回転数とシ リンダ速度測定結果をTable 2に示す. 所定の位置で相互方 向に速度が切替わり, 移動時には指示された速度で移動し ている様子がわかる. 10段階の切替えを終了し, 最終的に $0 \mathrm{~mm}$ の位置まで復帰するのに約18秒費やしている，累計移 動距離（変位）が900m岸ので平均移動速度は $50 \mathrm{~mm} / \mathrm{s}$ である. 空気圧シリンダの速度制御としてはかなり遅い領域である が，図で示されるように安定して移動している様子がわか る. 双方向型コンプレッサを直接制御に用い, インバータ 周波数操作をすることで安定した速度制御ができた。 ポン プ回転数とシリンダ速度の関係をFig. 9に示す. 回転数が 高くなるにつれシリンダ速度が速くなるが傾きが緩やかと なる. トルク不足によるACモータのスリップ現象, ベー ンとハウジングとの隙間からの内部空気漏れが原因と考え

Table 1 Velocity control program chart

\begin{tabular}{|c|c|c|}
\hline $\begin{array}{c}\text { Switching position } \\
(\mathrm{mm})\end{array}$ & $\begin{array}{c}\text { movement distance } \\
(\mathrm{mm})\end{array}$ & $\begin{array}{c}\text { Specified speed } \\
(\mathrm{bit})\end{array}$ \\
\hline 75 & 75 & 50 \\
\hline 56.25 & -18.75 & -10 \\
\hline 93.75 & 37.5 & 20 \\
\hline 37.5 & -56.25 & -30 \\
\hline 112.5 & 75 & 40 \\
\hline 18.75 & -93.75 & -15 \\
\hline 131.25 & 112.5 & 25 \\
\hline 0 & -131.25 & -30 \\
\hline 150 & 150 & 50 \\
\hline 0 & -150 & -100 \\
\hline
\end{tabular}


Table 2 Static characteristic of alternate direction air compressor

\begin{tabular}{|c|c|c|c|}
\hline $\begin{array}{c}\text { Input sgnal } \\
(\mathrm{bit})\end{array}$ & $\begin{array}{c}\text { Frequency } \\
(\mathrm{Hz})\end{array}$ & $\begin{array}{c}\text { Push velocity } \\
(\mathrm{m} / \mathrm{s})\end{array}$ & $\begin{array}{c}\text { Pull velocity } \\
(\mathrm{m} / \mathrm{s})\end{array}$ \\
\hline 30 & 21 & 0.114 & 0.173 \\
\hline 40 & 28 & 0.215 & 0.265 \\
\hline 50 & 35 & 0.298 & 0.332 \\
\hline 60 & 42 & 0.367 & 0.381 \\
\hline 70 & 50 & 0.369 & 0.395 \\
\hline 80 & 57 & 0.420 & 0.430 \\
\hline 90 & 64 & 0.443 & 0.465 \\
\hline 100 & 71 & 0.446 & 0.472 \\
\hline
\end{tabular}

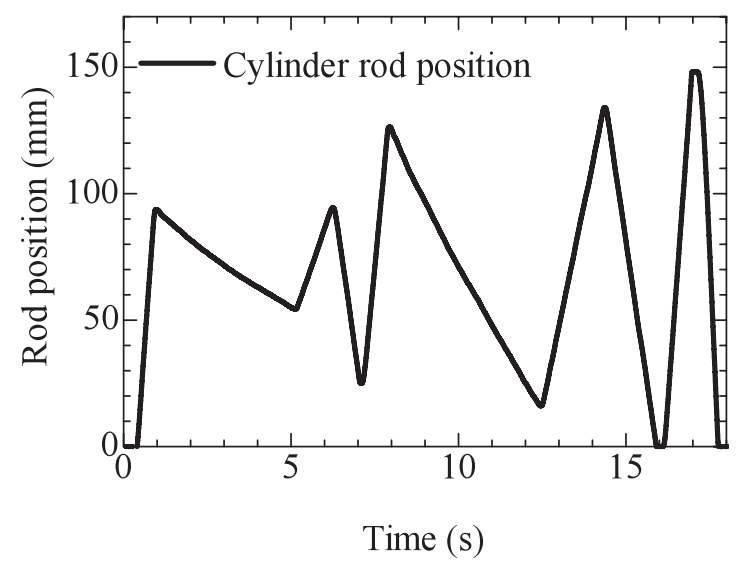

Fig. 8 Experimental result of position control by alternate direction air compressor

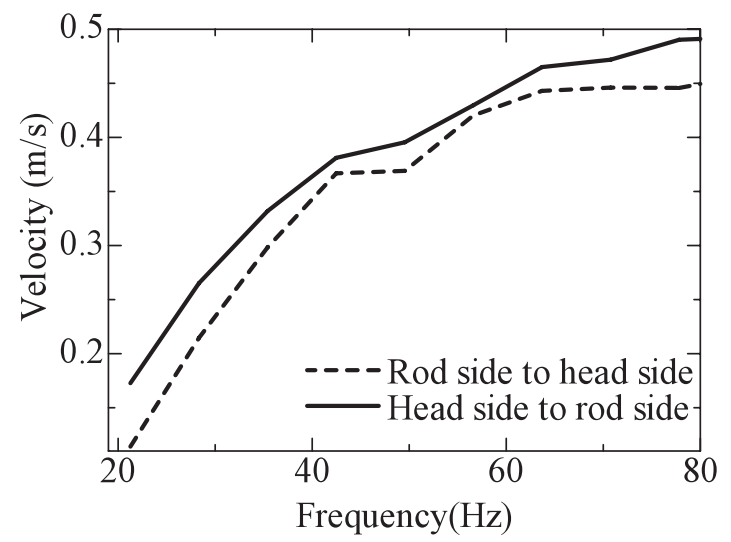

Fig. 9 Velocity vs frequency

られる。

指定速度のビット值を更に小さくして，より低速度で移 動させたときの結果をFig. 10に示す．このときの移動速度 は1.26mm/sである．極端に速度が遅い場合速度の摇らぎは 認められるが，従来不可能であった極低速領域のシリンダ 速度制御ができていることになる。

\section{3 空気圧シリンダの位置制御}

先の速度制御の結果により, 双方向型コンプレッサを用

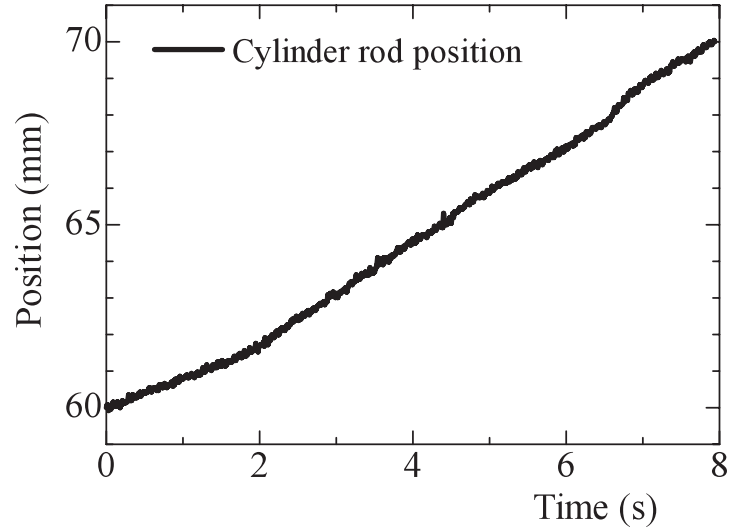

Fig. 10 Experimental result of low speed control

いて直接シリンダ位置の制御が可能であることが既に示さ れている。この節での位置制御では，PI制御を用いた フィードバック制御をおこなっている. PI動作は時点 $k$ に 扔ける目標位置 $r(k)$ とシリンダロッド位置 $p(k)$ との誤差 $e(k)$

$$
e(k)=r(k)-p(k)
$$

を用い制御入力 $u(k)$ は比例ゲイン $K_{p}$, 積分ゲイン $K_{i}$, サン プリングタイム $T_{s}$ を用いて次式の様にあらわされる.

$$
u(k+1)=K_{p}\left[e(k)+K_{i} T_{s} \sum_{i=0}^{k} e(i)\right]
$$

使用したシリンダは速度制御で用いたものと同じである。 位置制御では行程端から移動させてシリンダ中間位置であ る75mmの位置に中間停止させた. 負荷は $3 \mathrm{~kg}$ 質量負荷と した. Fig. 11にPIパラメータを調整して，オーバーシュー 卜なく最も速やかに整定させた結果を示す。濃い線がシリ ンダ位置を，薄い線がPI制御器からの制御信号を表す。制 御信制御信号が段階的であることから，移動速度がやや段 階的になっているかも知れない. しかし移動自体が不安定 になることはなく，最終的には $75 \mathrm{~mm}$ の位置に $0.18 \mathrm{~mm}$ 以内の 誤差で整定させることができた。このような位置決めには, 従来, 高精度なサーボ弁の使用が必要であったが，コンプ レッサを直接制御に用いて位置決めがおこなえることが示 された。

整定を更に早めようとPIパラメー夕を調整した結果を Fig. 12に示す. シリンダ移動速度を増すとオーバーシュー 卜を発生した。 この場合コンプレッサが逆方向に動作して 最終的には所定の精度で位置決めができているが, 整定ま でに時間がかかっている.

空気圧シリンダのシリンダロッドの位置制御において, Fig. 13はシリンダ内圧力変化を示した図である. シリンダ の目標停止位置は, シリンダロッドの長さの中間程度であ る75mmの位置とする. 信号入力をしてからシリンダロッド が目標位置に達するまでおよそ4.5秒かかった，その後，コ ンプレッサを低速で運転させることで十分に保持すること が確認された．Fig. 13に示す圧力変化ではシリンダが動き 出す瞬間に最も大きな圧力差が生じていること, そしてそ 


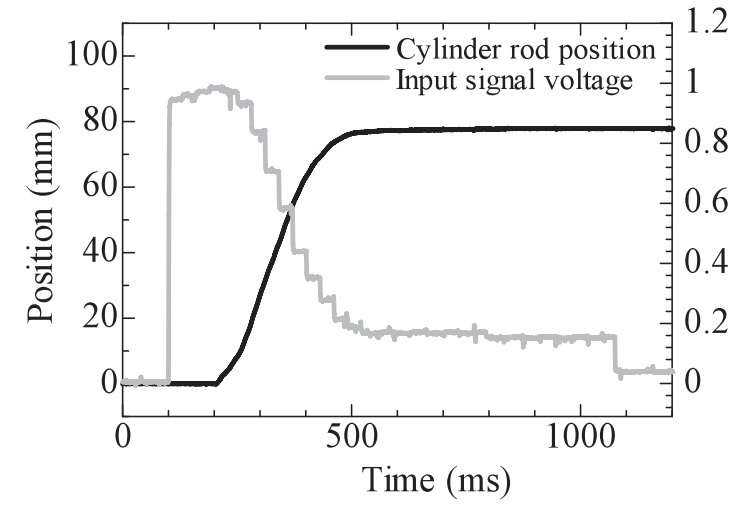

Fig. 11 Experimental results of step response

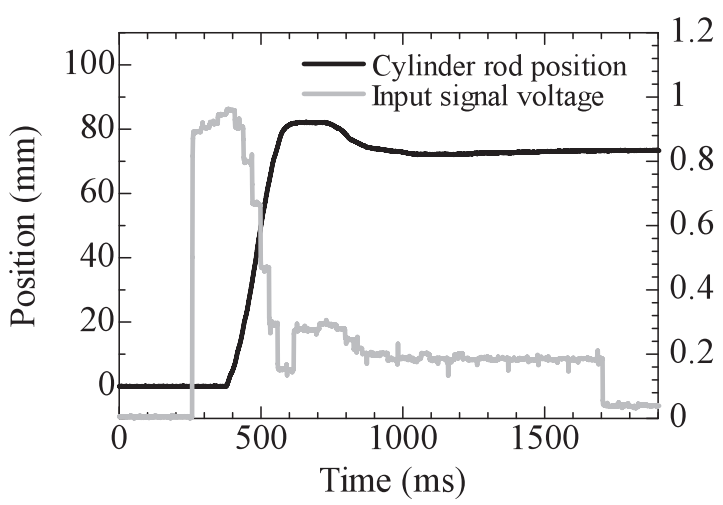

Fig. 12 Experimental results of step response

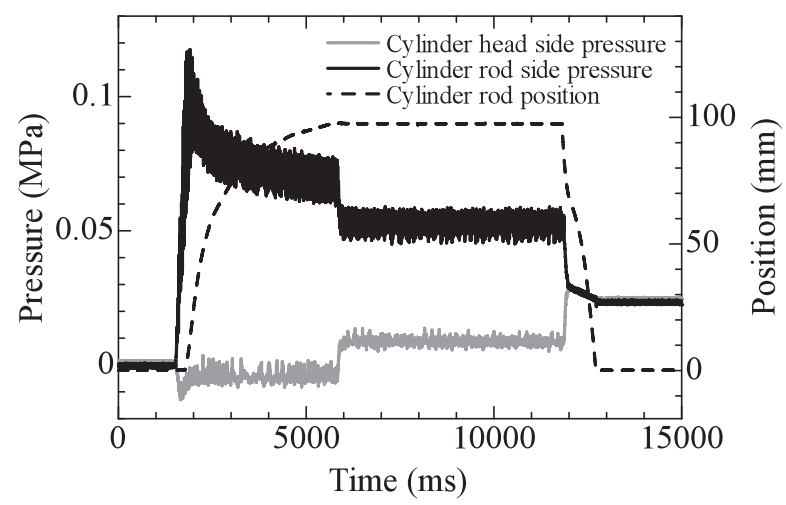

Fig. 13 Experimental results of step response $(\mathrm{Load}=3.0 \mathrm{Kg})$

の後圧力差が減少していることがわかる．コンプレッサの 運転を止めるとシリンダロッドは動いてしまったが, コン プレッサを低速回転させておけばシリンダに負荷をかけて も位置の固定化が可能であることが示された.

\section{4 排出空気量の検証}

双方向型コンプレッサを使って提案した回路は本質的に 空気の排出がない，排気空気に含まれるミストなどが嫌わ れる領域で利用できる. 本研究による空気圧シリンダ駆動 回路は, 全て, 空気漏れを特に限定していない一般品で試 作している.したがって実際にはシリンダや配管からの空 気漏れが生じていると予想されるので，一般的な回路（Fig. 7）を比較対象に用いて, 排気空気量の削減効果を実験に

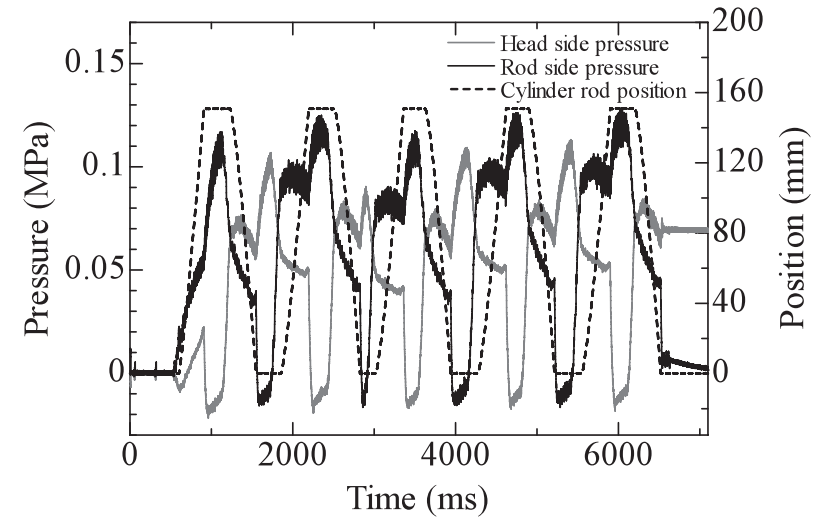

Fig. 14 Pneumatic cylinder reciprocating experiment by alternate direction air compressor

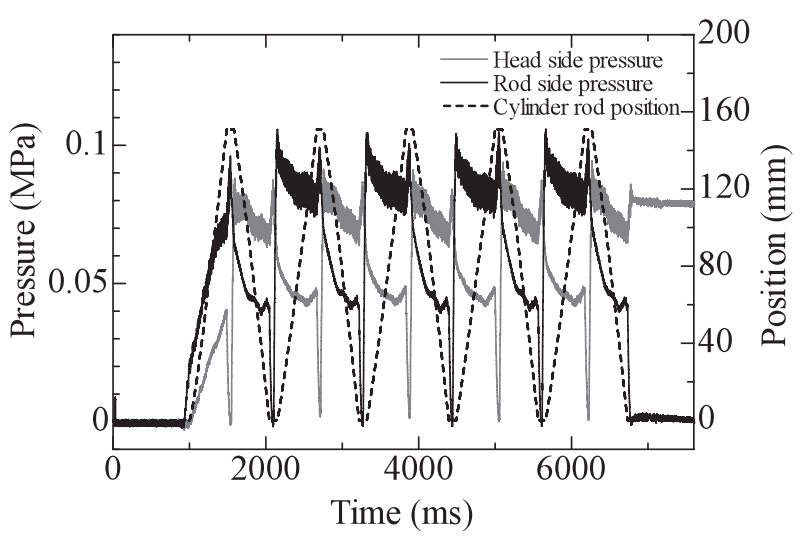

Fig. 15 Pneumatic cylinder reciprocating experiment by air suction system

より調べた. 条件を揃えるため基本的に同じ機器を使って いる. シリンダや配管から大気への空気の漏れを直接計測 することは困難なので, 双方向型コンプレッサ回路 (Fig. 6）ではチェック弁を通過する流量を計測する. 定常状態 であれば，大気への漏れの分だけチェック弁から補充が行 われると考えたからである。一方，毎回大気から吸引する 一般的な回路では, 方向制御弁から大気に放出される空気 量を計測した，双方向型コンプレッサを使った回路では， 動作を開始後最初の 1 往復時に大気から殆どの空気を吸引 する. それ以後は, 同じく空気が繰り返し使われるためほ ぼ定常になる. したがって, 最初の動作を含む 5 往復まで の空気量で比較した. 双方向コンプレッサ回路の結果を Fig. 14に，一般的な回路の結果をFig. 15に示す.

Table 3に排出空気量測定結果を示す. 当然のことではあ るが, 毎回全ての空気を大気から吸引する場合の排気量は 毎回変わらないのに対し, クローズド回路では 4 往復以後 では毎回 0.01 l で一定になっている. 初めの 3 往復で定常 になったと考えられるが，それ以後でも毎回吸引が行われ ている.これがシリンダや配管からの漏れに相当すると考 えられる. 漏れの少ないシリンダを使うとより削減効果が あるが，定常時では大気から吸引する場合のわずか $5 \%$ \%゙ ある。 
Table 3 Integrated supply flow rate

\begin{tabular}{|c|c|c|c|}
\hline & \multicolumn{2}{|c|}{ Flow rate $[\ell]$} & \\
\hline & Alternate $^{\text {a) }}$ & Air suction $^{\text {b) }}$ & Reduction rate \\
\hline 1st & 0.05 & 0.23 & $78.26 \%$ \\
\hline 2nd & 0.02 & 0.23 & $91.30 \%$ \\
\hline 3rd & 0.02 & 0.21 & $90.48 \%$ \\
\hline 4th & 0.01 & 0.22 & $95.45 \%$ \\
\hline 5th & 0.01 & 0.22 & $95.45 \%$ \\
\hline total & 0.11 & 1.11 & $90.09 \%$ \\
\hline
\end{tabular}

a) Air drive circuit by alternate direction air compressor b) Air drive circuit by air suction system

\section{5 空気の圧縮エネルギ回生による省エネルギ}

排気側空気を吸引利用する構成としたとき，もっとも注 目される側面として, 空気の膨張エネルギを再利用できる 結果, 省エネルギ効果が期待できる点にある. ただし, 省 エネルギ効果はコンプレッサの効率, 運転状況も含めた広 範囲な観点からの論議が必要であろう.

今回は回生による省エネルギ効果を検証した。すなわち， 同一のコンプレッサを用い, 双方向型コンプレッサ回路の ように排気側空気を吸引利用したとき，あるいは，一般的 な回路のように毎回大気から吸引したとき，同じ作業内容 についての消費電力を比較した. Fig. 14, 15より圧力・シ リンダ速度を用いてコンプレッサの理論消費電力を算出し, 併せて電力計により実際の消費電力を計測した，排出空気 量計測の場合と同様に一般的な回路の動作が定常になる, 動作開始後 5 往復目までの結果で比較した. 結果をTable 4 に示す.

事前の大まかな予測では, 前者の回路では 5 往復合計で, 空気の膨張エネルギをそのまま大気に排出する後者の大気 吸引回路に比べ, $50 \%$ の電力量を抑えることが出来そう であった，しかし実際に実験をしてみると低常時での削減 率は約20\%ほどであった. このように予測との差が大きく なったのは, シリンダロッドの移動方向を切替える際に, 電動モー夕の慣性が作用するため余計な電力を必要とした ことが挙げられる.この点に関しては, 電動モータの運転 を効率よく制御することで解消できる問題であり，より多 くの省電力化を目指すことが出来る.

最初の 1 往復目に注目するとFig. 6の回路は, 大気から 吸引するFig. 7の回路よりも15.2\%も多くの電力を必要とし た.これはFig. 6のクローズド回路ではシリンダ動作の開 始時に，シリンダ内圧力が大気圧となっている状態からの 起動では, 最初の往復時に大気からチェック弁を介して空 気を吸引する必要がある。この際にチェック弁が負荷とな り, 大気吸引回路よりも多くの電力を必要としたと考えら
Table 4 Comparison of theoretical and measured value of power consumption $(\mathrm{W} \cdot \mathrm{s})$

\begin{tabular}{|c|c|c|c|c|c|c|}
\hline & \multicolumn{2}{|c|}{ Alternate $^{\text {a) }}$} & \multicolumn{2}{c|}{ Air suction ${ }^{\text {b) }}$} & \multicolumn{2}{c|}{ Reduction rate } \\
\hline & Theoretical & Measured & Theoretical & Measured & Theoretical & Measured \\
\hline 1st & 139 & 296 & 228 & 257 & $39.0 \%$ & $-15.2 \%$ \\
\hline 2nd & 167 & 335 & 346 & 406 & $51.7 \%$ & $17.5 \%$ \\
\hline 3rd & 167 & 336 & 346 & 406 & $51.7 \%$ & $17.2 \%$ \\
\hline 4th & 165 & 329 & 346 & 406 & $52.3 \%$ & $19.0 \%$ \\
\hline 5th & 164 & 330 & 346 & 406 & $52.6 \%$ & $18.7 \%$ \\
\hline total & 802 & 1,626 & 1,612 & 1,881 & $50.2 \%$ & $13.6 \%$ \\
\hline
\end{tabular}

a) Air drive circuit by alternate direction air compressor

b) Air drive circuit by air suction system

れる. 回路構成についても検討の余地がある.

\section{4. 結言}

本研究では双方向型コンプレッサを開発し，これが実用 的な性能を持つことを示した. つぎに, 双方向型コンプ レッサを空気圧シリンダの駆動に用いたときの優位性につ いて評価検討をおこなった.

まず，サーボ弁や速度制御弁など外付けの制御機器を用 いることなく, シリンダの動作方向, 動作速度, 位置決め 制御ができることを示した. とくに, 従来の空気圧シリン ダでは不可能であった $1 \mathrm{~m} / \mathrm{s}$ 程度の極低速度制御が実現で きた.

さらに空気の膨張エネルギを回生すれば，大気からの吸 引・排気方式に比べ省エネルギ化が計れることを示した. 今後より実用的な条件において試験を進める.

最後ではあるが, この研究に絶大なる支援をいただいた， SMC株式会社殿ならびに関係各位様に感謝の意を表する。

\section{参 考 文 献}

1 ）馬衛東, 池尾茂 : 定圧力源システムにおける油圧シリ ンダの位置決め制御, 日本フルードパワーシステム学 会論文集, Vol. 34, No. 5, p. 99-105 (2003)

2 ）八才継紅, 池尾茂, 桜井康雄, 高橋浩爾 : 定圧力源シ ステムを用いたハイブリッド車両の省エネルギー効果, 日本フルードパワーシステム学会論文集, Vol. 30, No. 1, p. 20-27 (1999)

3 ) 韓建海, 則次俊郎, 高岩昌弘 : ロータリアクチュエー 夕を用いた小型コンプレッサの開発, 日本フルードパ ワーシステム学会論文集, Vol. 32, No. 5, p. 111-117 (2001)

4 ） カハルサムサク, 則次俊郎：小型コンプレッサを用い た空気圧アクティブサスペンションの制御, 日本フ ルードパワーシステム学会論文集, Vol. 33, No. 3, p. 6368 (2002) 